\title{
The Ottawa Field-Naturalists' Club Awards for 2015, presented April 2016
}

\author{
Eleanor Zurbrigg, Irwin Brodo, Julia Cipriani, Christine Hanrahan, Ann MacKenzie, and Karen \\ MCLACHLAN HAMILTON
}

On April 2 ${ }^{\text {nd }}, 2016$ members and friends of the Ottawa Field-Naturalists' Club gathered for the Club's Awards Night at St. Basil's Church in Ottawa to celebrate the presentation of awards for achievements in the previous year. Awards are given to members or nonmembers who have distinguished themselves by accomplishments in the field of natural history and conservation, or by extraordinary activity within the Club. Four Club awards were presented for 2015, for: (1) further-

ing the knowledge of natural history in the Ottawa area, (2) promoting a communications plan for the Club, (3) long time service as Book Review Editor for one of the Club's publications, and (4) protecting ecologically valuable land in the Ottawa area.

As well, two President's Prizes were presented in recognition of unusual support of the Club's finances and operations, and Club communications.

\section{Honorary Member: Robert E. Lee}

This award is presented in recognition of outstanding contributions by a member or non-member to Canadian natural history or to the successful operation of the Club. Usually people awarded an honorary membership have made extensive contributions over many years.

The Ottawa Field-Naturalists' Club, the Ottawa community, and indeed the country has benefitted from the skill, dedication, and vision of Robert E. Lee. For 30 years, Rob has been leader of the Macoun Field Club, the OFNC-sponsored natural history club for youths 818 years of age. By so doing, he has created an entire generation of conservationists, biologists, chemists, and teachers in the field of natural history. He has done this by virtue of his love and respect for children and their natural curiosity, his keen interest in the natural world, and his superb organizational skills, not to mention his wit, imagination, and humanity. To have such an extraordinary person in our midst is a gift to be treasured and applauded.

But Rob Lee is not only the inspired and inspiring leader of a natural history club for children. His accomplishments also include insightful observations, carefully executed experiments, and well-written reports on a broad realm of nature, including worms, frogs, plants, and lichens. His documentation of the changes in the Greenbelt area near Stony Swamp over a 40-year period with detailed and accurate, periodically updated vegetation maps has given researchers an unparalleled look

into the evolution of suburban natural areas over time. It is perhaps the most complete documentation of its kind in the country.

His knowledge of lichens has allowed him to do research and prepare status reports on a number of rare lichens for the Committee on the Status of Endangered Wildlife in Canada (COSEWIC), doing innovative investigations that deserve more recognition than they've received.

As a young man, Rob attended the University of Guelph and then travelled through the Arctic by himself, making discoveries and following in the footsteps of his archeologist father, Dr. Thomas E. Lee. His exceptional skills as a writer were put to good use when he served as scientific editor and writer and, later, when helping young writers in the Macoun Field Club prepare their first scientific contributions published in the club's own journal, The Little Bear.

The Ottawa Field-Naturalists' Club previously recognized Rob's contributions to the Club over the years by awarding him the 1990 George McGee Service Award and 2008 Mary Stuart Education Award, both for his work with the Macoun Club; and the 2000 Anne Hanes Natural History Award for his studies of Leopard Frogs. The OFNC is now delighted to add Rob Lee to its list of distinguished Honorary Members.

(Prepared by Irwin Brodo)

\section{Member of the Year: Lynn Ovenden}

The Member of the Year award recognizes a member judged to have contributed the most to the Club in the previous year.

We are recognizing Lynn Ovenden as this year's Member of the Year for her energy, initiative, and willingness to support the Club. Her contributions include: - overseeing and actively participating in the development of the OFNC communication plan, which

includes a proposal for a re-design of the Club's website;

- inviting students from Ottawa and Carleton Universities to write blogs for the OFNC site to report on the Club's activities;

- suggesting and planning several outings for the Events Committee, all of which were very well attended; and 
- stepping up to support the decision to refresh the Fletcher Wildlife Garden Interpretation Centre.

With the goals of attracting and retaining members to support the Club's work, and of strengthening and simplifying the Club's online presence, Lynn and the Education and Publicity Committee hired a consultant to support their initiative. After months of work focused on surveying members and distilling the data from members, their report was tabled at the May 2015 Board meeting. Recommendations included modernizing the OFNC web site, centralizing and coordinating communication, promoting a word of mouth campaign to grow membership, and broadening the Club's use of social media. Since the Board's acceptance of the recommendations, Lynn and members of the Education and Publicity Committee have dedicated hundreds of hours to consultation and committee work to move the action plan along.

Under Lynn's leadership, the Education and Publicity Committee has been posting blogs on ofnc.wordpress .com, spreading the word and reporting on the Club's outings, monthly meetings, reports from participants in Ontario Nature's Youth Summit, and other topics of interest to members.

\section{George McGee Service Award: Roy John}

The George McGee Service Award is given in recognition of a member who has contributed significantly to the smooth running of the Club over several years.

Most members have either met or heard of Roy John over the years, for his contributions to the Club are extensive. He has been an active member of the OFNC, in various capacities, even when he did not reside in Ottawa.

To OFNC members, Roy is probably most recognized for his book reviews published in The Canadian Field-Naturalist $(C F N)$. He assumed the role of Book Review Editor in 2003, stepping in when the former editor died suddenly, and continued in this position until 2016. Throughout the years he has read and reviewed more than 250 books, 145 articles, and 120 popular publications, as well as several handbooks, book chapters, and consultant reports. The range of topics covered is as wide as his personal experiences: from birds and field guides to botany, mycology, zoology, and even anthropology. His reviews often contain personal insight and include interesting bits of information that only someone familiar with the subject would know. The reviews are thoughtful, candid, and a pleasure to read.

Another responsibility as Book Review Editor was to compile a list of titles that may be of interest to $C F N$ readers. Constantly finding new books is a difficult task on its own, let alone finding someone to review them;
Lynn supported the Events Committee on a few occasions over the course of 2015. On the May long weekend, she coordinated a series of outings which included a visit to the Gervais property close to Westmeath on the Ottawa River, an afternoon of birding at Westmeath Provincial Park with the Pembroke Area Field Naturalists Club, an evening of mothing with Diane Lepage at the Shaw Woods Outdoor Education Centre, and a guided walk through the old growth forest in Shaw Woods the next day. Participants were invited to camp in the area or stay in one of the local motels.

When the decision was made to refresh the Fletcher Wildlife Garden Interpretation Centre and to replace some of the furniture in the Centre last fall, Lynn joined the group working to clear out the Centre, decide what items to keep, prepare the space for painting, and then put it all back together.

Beyond her committee work in 2015, Lynn volunteered at the Fletcher Wildlife Garden, weeding and supporting Ann Prescott, who staffs the sales table at monthly meetings.

It is for her commitment to the Club and her energetic approach to every project she has tackled that we are recognizing Lynn Ovenden as Member of the Year for 2015.

(Prepared by Julia Cipriani)

however, more often than not, readers would find a new title review in the next or the following issue of $C F N$.

Many know Roy for his birding and photographic skills. He is a passionate birder and an intrepid traveler, missing only a handful of countries. He has led countless local birding field trips and has been involved in the biennial Pelee trip these past few years. Roy has also given numerous talks, often willing to fill in at a moment's notice, and has introduced Club members to parts of the world few have managed to see. His passion for birds has led to his being Editor of The Blue Jay (the Saskatchewan Natural History Society) and OFO News (Ontario Field Ornithologists), and being a contributor to the Atlas of the Breeding Birds of Ontario. In addition, Roy gives presentations about birds at seniors' residences throughout Ottawa.

Roy has been active on the Council (now Board) in numerous capacities. Since joining the OFNC in 1984, he served on the Council in 1987, was Recording Secretary in 1988, and was Vice-President in 1989 - 1990 and 2000 - 2003. In 1991 he served as President. He was Chair of Excursions and Lectures (Events) in 2001 $-2003$.

It is for all these reasons that we are awarding Roy John the George McGee Service Award for 2015.

(Prepared by Karen McLachlan Hamilton, with input from Francis Cook and Frank Pope) 


\section{Conservation Award - Non-Member: Miller Paving Limited}

This award is given in recognition of an outstanding contribution by a non-member to the cause of natural history conservation in the Ottawa Valley, with particular emphasis on activities within the Ottawa District. We are recognizing Miller Paving Limited for noteworthy ecological land protection measures in the Braeside Quarry.

The aggregate industry has long had a bad name amongst those wishing to preserve natural habitats. It is not difficult to understand the dismay when a quarry operator moves in and forests and meadows vanish. So it's not surprising that the proposal by Miller Paving to expand their long-standing Braeside Quarry operation into a portion of Renfrew County's Braeside Alvar caused considerable concern in and about the Arnprior area. Local residents presented a variety of arguments against the quarry expansion, many addressing the protection needs of the rare alvar vegetation and flora. Miller Paving undertook the lengthy process of biophysical investigation of the site required to satisfy a wide range of provincial environmental regulations. Considerable discussion, debate, and controversy took place amongst numerous interested parties as these investigations unfolded. Ultimately, as is often the case, the issue was heard before the Ontario Municipal Board (OMB).

In October 2015 the OMB concluded that Miller Paving's natural environment conservation plan satisfied the necessary provincial environmental protection requirements. The Board disapproved of some parts of the development proposal but ruled that its ecological protection measures were sound. What is of particular interest to naturalists and conservations, however, is the unusual - apparently unique - degree to which the project's conservation plan provides for the protection of significant ecological features and functions.

The quarry expansion plan establishes an ecologically self-sustaining Significant Wildlife Habitat Protec-

\section{President's Prize: Ken Young}

This award is given at the President's discretion for singular contributions to our Club that do not quite fit the other Club awards categories.

Being the Treasurer of any organization is a demanding job. Being the Treasurer of a club the size and complexity of the OFNC is almost a full time assignment. Since January 2012 Ken Young has made sure that all our bills are paid and the money is accounted for.

Our Club was recently the beneficiary of a very generous bequest from Violetta Czasak. Ken took on the role of Trustee, hired a lawyer, and together they handled this sizeable bequest. It was a huge job. So when we delight in our ability to undertake many worthwhile projects due to this generous bequest, we have Ken's diligence and good sense to thank for it.

This is not all he has done on our behalf. Because the subscription manager of the CFN moved away, the tion Area of over 24 ha consisting primarily of globally rare alvar forest, as well as a comprehensive set of the regionally significant floral and faunal features known from the much larger Braeside Quarry property. Importantly, the Protection Area is legally fixed in place by both the project's approved Site Plan and municipal bylaws. A particularly intriguing aspect of the plan is that, even after quarry expansion is completed (likely 80 or more years away), the Protection Area will continue to sustain the largest populations of provincially rare Ram's-head Orchid (Cypripedium arietinum) and Neglected Milk-vetch (Astragalus neglectus) known anywhere. In addition, the plan includes a substantial allowance for wildlife corridors and ground water protection, and provides for a decade-long monitoring program of the site's ecological integrity.

The key to the success of the Braeside protection plan was the property owners' early recognition (even before the OMB process was initiated) of the exceptional ecological values present there and exceptional measures that would be required to protect them. They quickly accepted a recommendation that approximately half of the core alvar should be protected from disturbance. This greatly exceeds the normal size of aggregate Protection Areas. Indeed, Miller Paving's OMBcertified development proposal represents the most robust ecological protection plan of any aggregate development in eastern Ontario, if not the whole province.

It is important that examples of enlightened resource management be acknowledged and celebrated. Doing so encourages others in the aggregate and associated industries to produce their own Braeside-like protection plans. Miller Paving has set a new and important conservation standard for its industry. It is accordingly a most worthy recipient of the 2015 OFNC non-member Conservation Award.

\section{(Prepared by Christine Hanrahan, based on material provided by Dan Brunton)}

records of the CFN subscribers and authors had not been kept up-to-date. Again, Ken stepped in and sorted it all out... another huge job. Now we know who has paid for their subscriptions and which authors are in arrears.

As a member since 1985, Ken has contributed in other ways. Previously he tracked the money spent by the Fletcher Wildlife Garden, chaired the Finance Committee, and was active on the Conservation Committee. His reasoned comments around the Board table are always appreciated.

Before Ken and his wife Judy move to Maryland I wish to express our appreciation for all that Ken Young has done on our behalf, and that is why I am pleased to present Ken with the President's Prize.

(Prepared by Fenja Brodo, President) 


\section{President's Prize: Linda Burr}

This award is given at the President's discretion for singular contributions to our Club that do not quite fit the other Club awards categories.

We badly needed an editor for a special Club publication. When I said so at a monthly meeting in 2013 , Linda Burr volunteered. The project was the final editing and publication of the Larose Forest booklet, which was almost finished and had been mostly written by Gillian Marsten and Christine Hanrahan. Linda took that on, a tricky job that involved diplomacy as well as writing skills and working with printers. We now have a lovely publication to show for her efforts.

Linda has also been a mainstay of the Education and Publicity Committee, representing our club at various events around the city. Then she and Lynn Ovenden discovered Heather Badenoch and convinced the Board to hire Heather to help us analyze where we are going as a Club. Linda worked with Heather to formulate an appropriate survey and gather the results. As a result, we now have a Communications Plan and a vision that involves a revamped webpage (in the works) that will give us better communication within our Club and more visibility in our community.

For her inspiration and dedication to the several projects that she has taken on so successfully, I would like to honour Linda Burr with the President's Prize.

(Prepared by Fenja Brodo, President) 